\title{
Study on Present Status of Fish Biodiversity in Wetlands of Sylhet District, Bangladesh
}

\author{
Mohammed Ariful Islam ${ }^{1}$, Md. Jahidul Islam ${ }^{1}$, Sanzib Kumar Barman ${ }^{1}$, Farjana Morshed ${ }^{1}$, \\ Sabiha Sultana Marine ${ }^{2}$ \\ ${ }^{1}$ Department of Aquatic Resource Management, Faculty of Fisheries, Sylhet Agricultural University, Sylhet, Bangladesh \\ ${ }^{2}$ Department of Fisheries Technology and Quality Control, Faculty of Fisheries, Sylhet Agricultural University, Sylhet, Bangladesh
}

\section{Email address:}

arif.fisheries@gmail.com (M. A. Islam)

\section{To cite this article:}

Mohammed Ariful Islam, Md. Jahidul Islam, Sanzib Kumar Barman, Farjana Morshed, Sabiha Sultana Marine. Study on Present Status of Fish Biodiversity in Wetlands of Sylhet District, Bangladesh. Agriculture, Forestry and Fisheries. Vol. 4, No. 6, 2015, pp. 296-299. doi: 10.11648/j.aff.20150406.20

\begin{abstract}
The study was conducted to identify the present status of fish biodiversity in the wetlands of Sylhet district for a period of 12 months from January 2014 to December 2014. It was done by questionnaire interviews (QI) of fishers, focus group discussions (FGD), and key informant interviews (KII) and secondary data collection. During the study period, a total of 58 fish species under 21 families were recorded. The species availability status was remarked in four categories and obtained as 24 commonly available, 16 moderately available, 18 rarely available species. Highest number of commonly available species was found in October to December and lowest number of commonly available species was observed in March to April. Among 54 threatened fish species listed by IUCN Bangladesh, about 30 species were found 10-15 years ago in those wetlands but only 23 were found during the study period. It is revealed that there has been gradual reduction of fish diversity in the wetlands of the area of Sylhet district and average fish catch per fisherman per day was also reduced. Community based fisheries management, fishing gears maintenance, sanctuary establishment and management, implementation of fish acts and regulations, stocking of fish fingerling in the open waters, dredging of beels and raising public awareness can play a great role in conserving fish biodiversity.
\end{abstract}

Keywords: Biodiversity Reduction, Species Availability, Threatened Species, Conservation, Questionnaire Interview

\section{Introduction}

Aquatic biodiversity has enormous economic and aesthetic value and is largely responsible for maintaining and supporting overall environmental health (Hossain, 2012). Wetlands are one of the world's key natural resources (Khan et al., 1994). It is the transition between land and water and is the most productive ecosystems in the world. The biodiversity of the wetland ecosystem is variable in the world; it encompasses the range of living things, the degree of genetic variation, and the wealth of different habitats within a particular ecosystem.

The Ramsar Convention (1971) has defined wetlands as "areas of marsh, fen, peat land, or water, whether natural or artificial, permanent or temporary, with water that is static or flowing, fresh, brackish or salt, including areas of marine water the depth of which at low tide does not exceed six meters." Bangladesh is a home to at least 265 freshwater fish species (Rahman, 2005). Huge number of wetlands in various forms viz. rivers, haors, boars, beels, pond, ditch etc. support these large number of fish species. Among them, wetlands of Sylhet district are so important that contributes a huge amount of fish to the people of the country. The major wetlands in Sylhet district are Hailkar, Jilkar, Patharchauli, Jainkar, Chauldhani, Balai, Muria, Erali and Damrir haors.

At present time, reduction in the abundance and kinds of fish species from the inland waters or wetlands of Bangladesh is a burning issue in the country (Galib et al. 2009, Imteazzaman and Galib 2013). However, a total of 54 fish species of Bangladesh have been declared threatened by IUCN (IUCN Bangladesh 2000). All these findings clearly indicate the need for water body specific detailed biodiversity studies which is essential to assess the present status of fish biodiversity and sustainable management of a body of water (Galib et al. 2013a; Imteazzaman and Galib 2013). Though such type of research efforts are much common in neighbor 
countries like India (Dahanukar et al. 2012, Kharat et al. 2012, Baby et al. 2010, Jadhav et al. 2011, Patra 2011, Johnson and Arunachalam 2009, Heda 2009, Saha and Bordoloi 2009) but very few in Bangladesh.

To the best knowledge of the authors no previous research work has been conducted on fish biodiversity of Wetlands of Sylhet Districts, Bangladesh. So, this study will be very significant for the assessment of present status of fish biodiversity of Wetlands of Sylhet district, Bangladesh.

\section{Methodology}

\subsection{Description of Study Area}

Wetland fish species diversity was recorded in Sylhet district in Bangladesh from January to December in 2014. The selected wetlands were Hailkar, Jilkar, Patharchauli, Jainkar, Chauldhani, Balai, Muria, Erali and Damrir haors. The geographical location of the Sylhet district is an area of $3452.07 \mathrm{~km}^{2}$ (1332.85 sq. miters); it is bounded by Sunamgonj district on the west, Moulvibazar district on the south and Habogonj district on the south-west. The sites of the study are illustrated in Figure 1.

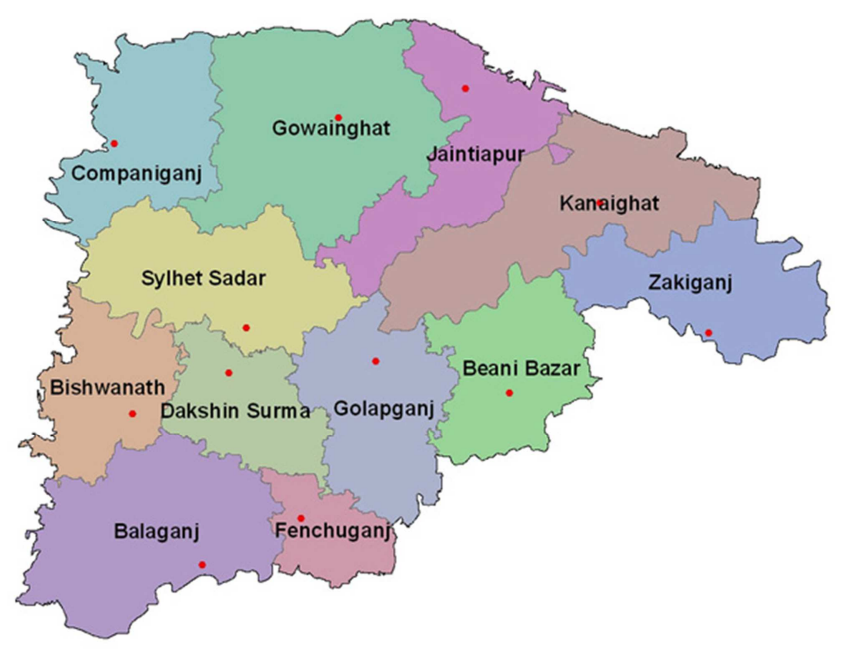

Figure 1. Location of wetlands at different upazilas of Sylhet district.

\subsection{Data Collection}

The study was based on field survey method where an appropriate questionnaire was prepared and used for collecting data from villagers of the surrounding study area under Sylhet district. During collection of data, both primary and secondary sources were considered to interpret the results.

Primary data were collected from 40 randomly selected fishermen through questionnaire interviews (QI) and focus group discussions (FGD) where Upazila Fisheries Officer (UFO), union parishad chairman \& members, leaders of the fisher community, fish market leaders, fish traders, fry traders and community people of the selected wetlands area were also present. The secondary information was collected from upazila fisheries office under Sylhet district, district fisheries office of Sylhet, books, journals and others. After collecting data, it was cross-checked through key informant interviews (KII) with Upazila Fisheries Officer (UFO), District Fisheries Officer (DFO), school teachers, local leaders and NGO workers in the study area. Finally data were analyzed by using Microsoft office excels 2010.

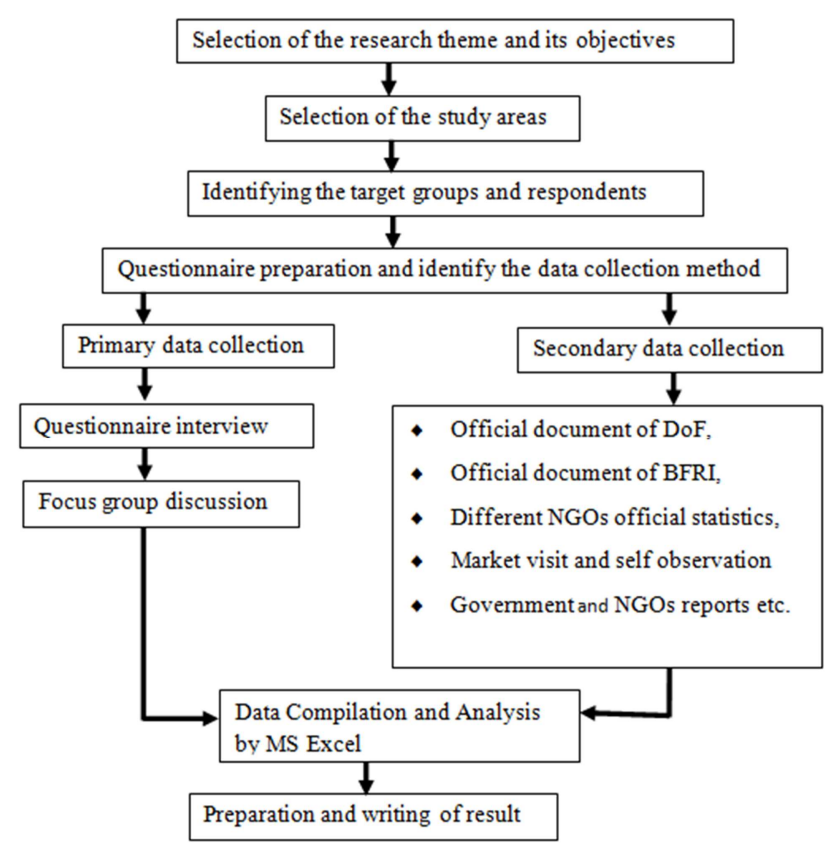

Figure 2. The design of the present study involved the steps.

\section{Results and Discussion}

According to the statement of local fishermen, a total of 58 fish species under 21 families were recorded. The recorded fish species with accurate taxonomy were identification by the cross-matching of definite fish characters from the text book, named "Freshwater Fishes of Bangladesh" (A. K. Ataur Rahman, Department of Fisheries, Matshya Bhaban, Dhaka). The recorded fish species are represented in the following table with their biodiversity status and IUCN status.

Table 1. List of recorded fish species with their status.

\begin{tabular}{|c|c|c|c|c|c|c|}
\hline SI. No. & Family & Local Name & Common Name & Scientific Name & Biodiversity status & IUCN Status \\
\hline 1 & Cyprinidae & Rohu & Indian Major Carp & Labeo rohita & $\mathrm{CA}$ & $\mathrm{NO}$ \\
\hline 2 & Cyprinidae & Carpio & Common Carp & Cyprinus carpio & $\mathrm{CA}$ & EX \\
\hline 3 & Cyprinidae & Kalibaush & Black Rohu & Labeo calbasu & $\mathrm{CA}$ & EN \\
\hline 5 & Bagridae & Tengra & Striped Dwarf Catfish & Mystus vittatus & $\mathrm{CA}$ & NO \\
\hline 6 & Siluridae & Boal & Freshwater Shark & Wallago attu & $\mathrm{CA}$ & NO \\
\hline
\end{tabular}




\begin{tabular}{|c|c|c|c|c|c|c|}
\hline Sl. No. & Family & Local Name & Common Name & Scientific Name & Biodiversity status & IUCN Status \\
\hline 7 & Siluridae & Modhu Pabda & Butter Catfish & Ompok pabda & $\mathrm{CA}$ & $\mathrm{EN}$ \\
\hline 8 & Siluridae & Pabda & Pabo Catfish & Ompok pabo & $\mathrm{CA}$ & EN \\
\hline 9 & Clariidae & Magur & Walking Catfish & Clarius batrachus & $\mathrm{CA}$ & NO \\
\hline 10 & Heteropneustidae & Shing & Stinging Catfish & Heteropneustes fossilis & $\mathrm{CA}$ & NO \\
\hline 11 & Cyprinidae & Tit Punti & Ticto Barb & Puntius ticto & $\mathrm{CA}$ & VU \\
\hline 12 & Cyprinidae & Teri Punti & One Spot Barb & Puntius terio & $\mathrm{CA}$ & NO \\
\hline 13 & Cyprinidae & Jat Punti & Spot Fin Swamp Barb & Puntius sophore & $\mathrm{CA}$ & NO \\
\hline 14 & Channidae & Taki & Spotted Snakehead & Channa punctatus & $\mathrm{CA}$ & NO \\
\hline 15 & Channidae & Shol & Snakehead Murrel & Channa striatus & $\mathrm{CA}$ & NO \\
\hline 16 & Mastacembelidae & Guchi Baim & Striped Spiny Eel & Macrognathus pancalus & $\mathrm{CA}$ & NO \\
\hline 17 & Mastacembelidae & Tara Baim & One Striped Spiny Eel & Macrognathus aculeatus & $\mathrm{CA}$ & VU \\
\hline 18 & Anabantidae & Baro Khalisha & Striped Gourami & Colisa fasciatus & $\mathrm{CA}$ & NO \\
\hline 19 & Anabantidae & Chota Khalisha & Honey Gourami & Colisa chuno & $\mathrm{CA}$ & NO \\
\hline 20 & Anabantidae & Koi & Climbing Perch & Anabas testudineus & $\mathrm{CA}$ & NO \\
\hline 21 & Ambassidae & Gol Chanda & Indian Glass Fish & Parambassis ranga & $\mathrm{CA}$ & VU \\
\hline 22 & Nandidae & Meni & Mud Perch & Nandus nandus & $\mathrm{CA}$ & VU \\
\hline 23 & Cobitidae & Gutum & Guntea Loach & Lepidocephalichthys guntea & $\mathrm{CA}$ & NO \\
\hline 24 & Palaemonidae & Sada Icha & Prawn & Macrobrachium sp. & $\mathrm{CA}$ & NO \\
\hline 25 & Cyprinidae & Catla & Indian Major Carp & Catla catla & MA & NO \\
\hline 26 & Cyprinidae & Mrigal & Indian Major Carp & Cirrhinus cirrhosus & MA & NO \\
\hline 27 & Cyprinidae & Grass Carp & Grass Carp & Ctenopharyngodon idella & MA & EX \\
\hline 28 & Cyprinidae & Silver Carp & Silver Carp & Hypophthalmicthys molitrix & MA & EX \\
\hline 29 & Cyprinidae & Mola & Carplet & Amblypharyngodon mola & MA & NO \\
\hline 30 & Cyprinidae & Darkina & Flaying Barb & Esomus danricus & MA & DD \\
\hline 31 & Channidae & Cheng & Asiatic Snakehead & Channa orientalis & MA & VU \\
\hline 32 & Bagridae & Golsha & Long Whiskered Catfish & Mystus cavasius & MA & VU \\
\hline 33 & Channidae & Gozar & Giant Snakehead & Channa marulius & MA & EN \\
\hline 34 & Mastacembelidae & Baro Baim & Two-track Spiny Eel & Mastacembelus armatus & MA & EN \\
\hline 35 & Sybranchidae & Cuchia & Gangetic Mud Eel & Monopterus cuchia & MA & VU \\
\hline 36 & Ambassidae & Lamba Chanda & Elongated Glass Perchlet & Chanda nama & MA & VU \\
\hline 37 & Gobiidae & Bele & Bar Eyed Goby & Glossogobius giuris & MA & NO \\
\hline 38 & Notopteriidae & Foli & Bronze Featherback & Notopterus notopterus & MA & VU \\
\hline 39 & Cobitidae & Bou Rani & Bengal Loach & Botio dario & MA & EN \\
\hline 40 & Tetraodontidae & Potka & Ocellated Puffer fish & Tetraodon cutcutia & MA & NO \\
\hline 41 & Cyprinidae & Goniya & Kuria Labeo & Labeo gonius & RA & EN \\
\hline 42 & Cyprinidae & Bata & Minor Carp & Labeo bata & RA & EN \\
\hline 43 & Cyprinidae & Dhela & Cotio & Osteobrama cotio & RA & EN \\
\hline 44 & Cyprinidae & Chela & $\begin{array}{l}\text { Finescale Razorbelly } \\
\text { Minnow }\end{array}$ & Chela phulo & RA & NO \\
\hline 45 & Cyprinidae & Shar Punti & Olive Barb & Puntius sarana & RA & $\mathrm{CR}$ \\
\hline 46 & Bagridae & Rita & Rita & Rita rita & RA & $\mathrm{CR}$ \\
\hline 47 & Bagridae & Ayre & Long Whiskered Catfish & Mystus aor & RA & VU \\
\hline 48 & Bagridae & Gagla & Menoda Catfish & Hemibagrus menoda & RA & NO \\
\hline 49 & Schilbeidae & Gharua & Gharua Bacha & Clupisoma garua & RA & $\mathrm{CR}$ \\
\hline 50 & Schilbeidae & Batashi & Indian Potasi & Pseudeutropius atherinoides & RA & NO \\
\hline 51 & Schilbeidae & Kajoli & Gangetic Ailia & Ailia coilia & RA & NO \\
\hline 52 & Pangasidae & Thai Pangus & Sutchi Catfish & Pangasius hypophthalmus & RA & EX \\
\hline 53 & Clupeidae & Chapila & Indian River Shad & Gaduasia chapra & RA & NO \\
\hline 54 & Anabantidae & Lal Khalisha & Dwarf Gourami & Colisa lalia & RA & NO \\
\hline 55 & Ambassidae & Lal Chanda & Indian Glass Perchlet & Parambasis lala & RA & EN \\
\hline 56 & Cichlidae & Tilapia & Mozambique Tilapia & Oreochromis mossambicus & RA & EX \\
\hline 57 & Hemiramphidae & Ekthute & Congaturi Halhbeak & Hyporamphus limbatus & RA & NO \\
\hline 58 & Palaemonidae & Golda & Prawn & Macrobrachium rosenbergii & RA & $\mathrm{NO}$ \\
\hline
\end{tabular}

$\mathrm{CA}=$ Commonly available, $\mathrm{MA}=$ Moderately available, $\mathrm{RA}=$ Rarely available.

$\mathrm{CR}=$ Critically endangered, $\mathrm{EN}=$ Endangered, $\mathrm{VU}=$ Vulnerable, $\mathrm{NO}=$ Not threatened, $\mathrm{DD}=\mathrm{Data}$ deficient and $\mathrm{EX}=\mathrm{Exotic}$ species.

\section{Recommendation}

- Fish sanctuary should be established in the selected wetlands area before breeding season.

- No fishing in the fish sanctuary in a defined time (several months) should be ensured.

- Overfishing should be prohibited in the wetlands area.

- Banded fishing gears (specially banded fishing nets) should be prohibited in the selected areas.

- Community based fisheries management (CBFM) should be established in the haor areas.

- Alternative earning source of the people of haor areas should be provided during banded season of fishing.

- Increasing awareness among the much people of surrounding wetland areas. 


\section{Conclusion}

Wetlands of Sylhet district are generally considered as a highly diversified zone of Bangladesh mainly for its rich aquatic biodiversity. According to the statement of the respondent fishermen, the total fish biodiversity is reducing drastically in the wetlands of Sylhet district due to lake of proper management. As a consequence, wetland ecosystem protection is important for species conservation and the protection of a sustainable environment.

\section{References}

[1] Baby F, Tharian J, Ali A and Raghavan R (2010). A checklist of freshwater fishes of the New Amarambalam Reserve Forest (NARF), Kerala, India. Journal of Threatened Taxa 2(12): 1330-1333.

[2] Dahanukar N, Paingankar M, Raut RN and Kharat SS (2012). Fish fauna of Indrayani River, northern Western Ghats, India. Journal of Threatened Taxa 4(1): 2310-2317.

[3] Galib SM, Naser SMA, Mohsin ABM, Chaki N and Fahad MFH (2013a). Fish diversity of the River Choto jamuna, Bangladesh Present status and conservation needs. International Journal Biodiversity and Conservation 5(6): 389395. DOI: 10.5897/IJBC2013.0552.

[4] Hossain, M., 2012. Biodiversity of Threatened Fish Species of Choto Jamuna River in Badalgachhi Area under Naogaon District. MS Thesis, Department of Fisheries Management, Bangladesh Agricultural University, Mymensingh, pp: 30-53.
[5] IUCN Bangladesh (2000). Red book of threatened fishes of Bangladesh, IUCN- The world conservation union. xii+116 pp.

[6] Jadhav BV, Kharat SS, Raut RN, Paingankar M and Dahanukar N (2011). Freshwater fish fauna of Koyna River, northern Western Ghats, India. Journal of Threatened Taxa 3(1): 1449-1455.

[7] Johnson JA and Arunachalam M (2009). Diversity, distribution and assemblage structure of fishes in streams of southern Western Ghats, India. Journal of Threatened taxa 1(10): 507-513.

[8] Patra AK (2011). Catfish (Teleostei: Siluriformes) diversity in Karala River of Jalpaiguri District, West Bengal, India. Journal of Threatened Taxa 3(3): 1610-1614.

[9] Rahman, AKA (2005). Freshwater Fishes of Bangladesh, second edition. Zoological Society of Bangladesh, University of Dhaka, Dhaka, Bangladesh, 263 pp.

[10] Saha S and Bordoloi S (2009). Ichthyofaunal diversity of two beels of Goalpara District, Assam, India. Journal of Threatened Taxa 1(4): 240-242.

[11] Rahman, A. K. A. (1989). Freshwater Fishes of Bangladesh. Zoological Society of Bangladesh. Department of Zoology, University of Dhaka. Dhaka-1000.

[12] Khan, M. S., Haq, S., Rahman, A. A., Rashid S. M. A. and Ahmed. H., 1994. Wetlands of Bangladesh. Bangladesh Centre for Advanced Studies \& Nature Conservation Movement. 